\title{
Surfactant Protein D Measurement
}

National Cancer Institute

\section{Source}

National Cancer Institute. Surfactant Protein D Measurement. NCI Thesaurus. Code C111322.

The determination of the amount of surfactant protein $D$ present in a sample. 